Article

\title{
Economic Sustainability of Payments for Water Yield in Slash Pine Plantations in Florida
}

\author{
Andres Susaeta *, José R. Soto, Damian C. Adams and Derek L. Allen \\ School of Forest Resources and Conservation, University of Florida, P.O. Box 110410, Gainesville, FL 32611, USA; \\ josesoto@ufl.edu (J.R.S.); dcadams@ufl.edu (D.C.A.); derek.allen@ufl.edu (D.L.A.) \\ * Correspondence: asusaeta@ufl.edu; Tel.: +1-352-846-0877; Fax: +1-352-856-1277
}

Academic Editor: Karina Schoengold

Received: 10 June 2016; Accepted: 26 August 2016; Published: 7 September 2016

\begin{abstract}
Forests play an important role with respect to water resources, and can be managed to increase surface- and groundwater recharge. With the creation of a forest water yield payment system, privately-owned forests, which comprise the majority of forest area in the Southeastern US, could become an important potential source of additional water supply. The economic tradeoffs between timber revenues and water yield are not well understood. To address this, we use the example case of slash pine production in Florida, and employ a forest stand-level optimal rotation model that incorporates forest management, and assessed a range of feasible water yield prices on forest profitability. Our analysis was limited to a range of water yield prices $(\$ 0.03, \$ 0.07$, and $\$ 0.30 \mathrm{~kL}^{-1}$ ) that would make water yield from slash pine economically competitive with water supply alternatives (e.g., reservoir construction). Even at relatively low water prices, we found that managing slash pine forests for both timber and water yield was preferred to managing just for timber when assuming an initial tree density less than 2200 trees $\cdot$ ha $^{-1}$. However, with higher levels of initial tree planting density and low water prices, managing slash pine for timber production alone was more profitable unless stands are heavily-thinned, suggesting that even mid-rotation stands could be included in a forest water yield payments program. Compared to low-tree planting density and lightly thinned slash pine forests, an intensive approach of planting a lot of trees and then heavily thinning them generated $8 \%$ to 33\% higher profits, and 11\% more ( $\$ 192 \mathrm{ha}^{-1}$ ) on average. We conclude that payments for water yield are economically feasible for slash pine stands in Florida, and would benefit forest landowners, particularly with higher prices for water yield.
\end{abstract}

Keywords: water yield; forest management; ecosystem services; payments; slash pine; economic sustainability

\section{Introduction}

Forests play an essential role in the welfare of the United Sates (U.S.) providing ecosystem services such as timber, carbon sequestration, biodiversity, and water. In the southern U.S., forests cover roughly $27 \%$ of the total land in the region and provide $58 \%$ of the total volume of roundwood harvested in the nation (around 298 million of cubic meters) [1]. Forests also play a pivotal role in the provision and quality of water. Forests mitigate flooding, reduce stormwater runoff, filter water, recharge groundwater, and regulate streamflows [2]—reducing water treatment costs [3]. In the southern U.S., forests provide $36 \%$ ( 322 billion kiloliters $(\mathrm{kL}) \cdot \mathrm{year}^{-1}$ ) of total available water supply [4]. Roughly 48 million people in this Region receive some portion of their water source from state and private forests [4]. Given that southern forests are mainly owned by nonindustrial private forest landowners—who hold $60 \%$ of total regional forestland ( 59.4 million hectares; [1])—management decisions by these landowners will have significant implications for sustaining the provision of timber and water to meet future demand for these ecosystem services. 
It is well established that climate change and urban sprawl will increase the vulnerability of forests and their associated ecosystems services, such as timber and water. We know that forest productivity is expected to increase with climate change [5], but these gains are likely be negatively impacted by invasive pests, hurricanes and wildfires [6], as well as water losses [2]. Although climate change related precipitation variability is large, the southern U.S. is expected to get drier over the next 50 years [7]. Continued urban sprawl is also a major concern in this area-around $20 \%$ of southern U.S. homes are located in wildland-urban interface areas [8]. By 2030, housing density is expected to have a substantial impact on watersheds where private forests have a significant footprint-increasing surface runoff and altering freshwater systems that prevent groundwater recharge-which puts the supply of water at risk [9]. Since forests are critical to the hydrological cycle, forest management practices (e.g., best management practices) have been identified as a cost-effective way to conserve water quality [10]. Here, we investigate whether the same may be true for forest-based water yield.

Thinning is a widely used forest management practice that improves overall forest health [11], reduces forest fire fuel loads [12], and minimizes tree competition for water and nutrients [13]. This practice has also been recommended as a water conservation strategy to increase water yield (the difference between precipitation and evapotranspiration) to local and regional stream flow and groundwater resources [14].

Through forest thinnings, water yield increases by reducing water lost to evapotranspiration, namely reducing leaf area and forest transpiration [15,16]. McCarthy and Skaggs [16] reported 35\% less evapotranspiration after a commercial thinning treatment of 15-year-old loblolly pine plantations, on mineral soils in North Carolina, as compared to unthinned controlled areas. Similarly, Grace et al. [17] found that removing $33 \%$ of basal area in a 15-year-old loblolly pine plantation doubled the water yield in the North Carolina Coastal plains. Edwards et al. [18] also found a large water yield increase $(23 \%)$ from pine thinning in the Ouachita Mountains of Arkansas. Furthermore, McLaughlin et al. [14] reported a cumulative increase of up to $64 \%$ in water yield, over a 25 -year slash pine rotation in Florida, by maintaining lower basal areas through thinnings-as compared to higher slash pine planting densities.

The monetary valuation of forest-based water yield may be an important aspect of ensuring the economic sustainability of forestlands, yet there has been little research on the tradeoffs between water and timber production and associated economic impacts in the southern United States. Understanding these tradeoffs may also facilitates the general public's understanding of societal benefits of forest-based ecosystems services in a more comprehensive way [19]. The majority of economic studies related to the valuation of water-related ecosystem services (e.g., water quality [20]) have focused on non-market valuation techniques such as stated and revealed preferences methods to estimate demand-side values [21,22], with very little focus on supply. In regards to forest ecosystems, the majority of studies have determined annual values (per hectare) by employing cost-based approaches [21], benefit transfer methods [23], production functions [24], and contingent valuation-based willingness to pay methodologies [25]. However, to date, no study has analyzed the implications of payments for water (and timber) production on profitability and optimal harvest decisions by the landowner at the forest stand level.

The objective of this paper is to determine the economic implications of payments for increased water yield on the profitability and optimal forest management of slash pine in Florida. Slash pine is a fast growing species, native to the southern U.S., that has been planted on more than 4.2 million hectares, 79\% of which occurring in Florida and Georgia [26]. With roughly 6.2 million hectares, these timberlands support approximately 80,000 jobs and generate around $\$ 16.3$ billion for the State of Florida [27]. With increased population growth and its commensurate utilization of natural resources, the vital role that forests can play in the hydrological cycle may become an essential element of a comprehensive water conservation strategy [14]. In the case of Central and North Florida, private and state forests could provide up to $50 \%$ of total water supply [4]. 
Our analysis provides a critical assessment of the relative economic performance of a slash pine stand in Florida when considering prices for timber and water. We present the assessment using two common metrics-land expectation values and optimal harvest ages-considering monetary benefits for increased water yield through thinnings. The remainder of our paper is a follows. In Section 2, we outline the economic model of slash pine for timber and water production. We also describe our slash pine growth and yield analysis, the monetary function for increased water yield, forest management scenarios, our economic parameters, and their current application of to slash pine forests. The results of our study are presented in Section 3, followed by a discussion in Section 4. Finally, we offer the concluding remarks of our study.

\section{Materials and Methods}

\subsection{Economic Model Specification}

Our stand level economic model was based on the Hartman approach [28], which determines the impacts of amenity values on the profitability of forestlands-in terms of the land expectation value $(L E V)$ - and its optimal forest management, assuming forestry use in perpetuity. The $L E V$ is the most commonly used indicator to assess forestry investments, and as stated by Samuelson [29]: (i) it is the correct method to determine at what age the forest should be harvested (rotation or harvest age); and (ii) other methods such as a single rotation method, IRR approach, and the maximum sustained yield are not well-suited to this purpose. Consequently, analyses involving a shorter time horizon will not allow us to appropriately determine the value of the forestland.

Following a similar notation to Hartmann [28], and Stainback and Alavalapati [30], the LEV $\left(\$ \cdot \mathrm{ha}^{-1}\right)$ at time $T$ can be defined as:

$$
L E V(T)=F+G
$$

where $F$ and $G$ represent, respectively, the net present value of timber benefits and amenity services over perpetual rotations. $F$ and $G$ can be expressed as follows:

$$
\begin{gathered}
F=\frac{P V(T) e^{-r T}+P_{t} V(t) e^{-r t}-c}{1-e^{-r T}}, T>t \\
G=\frac{\int_{0}^{T} A(s) e^{-r s} \mathrm{~d} s}{1-e^{-r T}}
\end{gathered}
$$

In Equation (2), $P$ represent the stumpage price, $V(T)$ is the merchantable wood production at time $T, P_{t}$ is the net price of thinned wood, $V(t)$ is the amount of thinned wood, $c$ represents the regeneration cost, and $r$ is the discount rate. In Equation (3), $A(s)$ represent the amenity function at time $s$. The numerators of Equations (2) and (3) represent, respectively, the net present value of timber benefits, and the present value of sum of the benefits from a flow of amenity for the first rotation of the forest stand. The denominators of both equations convert the expressions into a perpetual time series. The time $T$ that maximizes the $L E V$ is the optimal harvest age $\left(T^{*}\right)$. In our study, we assumed that $A(s)$ represents the monetary benefits of increased water yield through silvicultural management (thinnings) in slash pine forests.

\subsection{Growth and Yield Model}

We employed whole-stand growth and yield models for slash pine developed by Pienaar et al. [31] and Yin et al. [32], and modified to allow for multiple thinnings [33], that generate merchantable wood production $V(T)\left(\mathrm{Mg} \cdot \mathrm{ha}^{-1}\right)$ of slash pine stands. The following three main forest products, from thinnings or final harvests, were defined based on stem diameter at breast height and commercial diameter: sawtimber (stem diameter breast height $=29.2 \mathrm{~cm}$; top diameter $=17.8 \mathrm{~cm}$ ), chip-and-saw (stem diameter breast height $=19.1 \mathrm{~cm}$; top diameter $=15.2 \mathrm{~cm})$, and pulpwood $($ diameter breast height $=11.4 \mathrm{~cm}$; top diameter $=7.6 \mathrm{~cm}$ ). The main inputs of the growth and yield model are site 
index (SI) — the height of dominant and codominant trees at a reference age of 25 years [34]—and initial planting density. The site index was assumed to be $20 \mathrm{~m}$ (base age 25 years), and sixteen tree planting densities (TPDs) were considered: from 1000 trees $\cdot \mathrm{ha}^{-1}$ to 2500 trees $^{-h^{-1}} \mathrm{at}^{-1}$ increments of 100 trees $\cdot \mathrm{ha}^{-1}$.

The relationship of water yield and slash pine forests proposed by McLaughlin et al. [14] was used to determine the impacts of forest management activities on water production. Water yield $W$ $(\mathrm{mm})$ can be defined as:

$$
W=(1-E T / P P T) M P
$$

where $E T / P P T$ is the ratio between evapotranspiration and precipitation, and $M P$ is the mean annual precipitation $(\mathrm{mm})$. Equation (5) shows the ratio ET/PPT as a function of the slash pine stand leaf area index (LAI). This relationship was based on lower and upper limits of LAI of 2.3 and $7 \mathrm{~m}^{2} \cdot \mathrm{m}^{-2}$, respectively. Likewise, the lower and upper limits for the ratio ET/PPT were around 0.4 and 1 , respectively [14]. The ratio $E T / P P T$ is modeled as follows [14]:

$$
E T / P P T=0.06 L A I+0.54
$$

where $L A I\left(\mathrm{~m}^{2} \cdot \mathrm{m}^{-2}\right)$ is the stand leaf area index-the projected leaf area per unit ground surface area. $L A I$ is a critical parameter to determine forest productivity and detect changes in forest productivity through silvicultural treatments [35]. To determine the $L A I$, we employed the model developed by Gonzalez-Benecke et al. [35] in which LAI was determined as a function of the SI and stand density index (SDI), the number of trees of $25.4 \mathrm{~cm}$ diameter that the stand can support in one hectare for a given basal area [34]. Table 1 shows the parameter estimates and relationships to model the LAI.

Table 1. Leaf area index (LAI) model and parameters for slash pine.

\begin{tabular}{cc}
\hline Parameter & Model \\
\hline$L A I$ & $-\beta_{0} /\left(1+e^{-\left(\frac{S D I-\beta_{2}}{\beta_{1}}\right)}\right)$ \\
$\beta_{0}$ & $-1.307+0.147 S I$ \\
$\beta_{1}$ & $12.095+2.586 S I$ \\
$\beta_{2}$ & $327.234 /(1+(S I / 18.571))^{-4.929}$ \\
\hline
\end{tabular}

\subsection{Water Yield Valuation Function}

We defined the water yield valuation function, $A(s)$, as the monetary benefits of increased water yield between forest management regimes. To determine $A(s)$, we calculated the difference in water yield $(\Delta W)$ between intensively thinned and extensively thinned forest management activities for slash pine. We proceeded as follows: (i) we determined the $L A I$ for a extensively thinned slash pine management; (ii) with the calculated $L A I$, we determined the ratio ET / PPT using Equation (5); and (iii) we used the ratio $E T / P P T$ to determine water yield $W$ using Equation (4). We repeated the same steps to gauge the water yield $W$ for an intensively thinned slash pine management, and calculate $\Delta W$ between both forest managements. Finally, we determined the valuation function multiplying the water yield differential by the price of water production, which is expressed as:

$$
A(s)=P_{w} \Delta W ; \Delta W=W^{t}-W^{e t}
$$

where $W^{t}$ and $W^{e t}$ represent water yield under intensively thinning and extensively thinning regimes, respectively (although the most common water-related unit in the US is the gallon ( 1 gallon $=3.8 \mathrm{~L}$ ), we present the water yield in units of kiloliter ( $\mathrm{kL}$ ) (thousand liters) to remain consistent with SI units). 


\subsection{Baseline and Thinning Scenarios}

We defined sixteen extensive thinning scenarios (baselines) for each of the sixteen intensive thinning regimes scenarios (extensive thinnings are associated with a lower monetary investment by the landowner, and include thinnings that are fewer and involve a lower percentage of tree removal). The thinning schedules are presented in Table 2.

Table 2. Thinning scenarios for slash pine for different tree planting densities.

\begin{tabular}{|c|c|c|c|c|}
\hline \multirow{2}{*}{$\begin{array}{l}\text { Tree Planting Density } \\
\text { (TPD) (Trees.ha }{ }^{-1} \text { ) }\end{array}$} & Thinning Age (Years) & Intensity (\%) & Thinning Age (Years) & Intensity (\%) \\
\hline & \multicolumn{2}{|c|}{ Extensive Thinning Scenarios } & \multicolumn{2}{|c|}{ Intensive Thinning Scenarios } \\
\hline 1000 & 17 & 33 & 17,24 & 33 (each) \\
\hline 1100 & 16 & 33 & 16,22 & 33 (each) \\
\hline 1200 & 15 & 33 & 15,20 & 33 (each) \\
\hline 1300 & 14 & 33 & 14,19 & 33 (each) \\
\hline 1400 & 13 & 33 & 13,18 & 33 (each) \\
\hline 1500 & 13 & 33 & 13,17 & 33 (each) \\
\hline 1600 & 12 & 33 & $12,16,22$ & 33 (each) \\
\hline 1700 & 12 & 33 & $12,15,21$ & 33 (each) \\
\hline 1800 & 11 & 33 & $11,15,20$ & 33 (each) \\
\hline 1900 & 11 & 33 & $11,14,19$ & 33 (each) \\
\hline 2000 & 10 & 33 & $10,14,19$ & 33 (each) \\
\hline 2100 & 10 & 33 & $10,13,18$ & 33 (each) \\
\hline 2200 & 10 & 33 & $10,13,17$ & 33 (each) \\
\hline 2300 & 10 & 33 & $10,13,17$ & 33 (each) \\
\hline 2400 & 10 & 33 & $10,12,16$ & 33 (each) \\
\hline 2500 & 9 & 33 & $9,12,16$ & 33 (each) \\
\hline
\end{tabular}

We defined the thinning schedules based on a percentage range of the maximum Reineke SDI [34]. This approach requires maintaining a lower growing stock limit to preserve an adequate site occupancy, and an upper growing stock limit to avoid tree mortality and to maintain individual tree vigor [36]. For slash pine, lower and upper stocking levels can be found between $25 \%$ and $50 \%$ of the maximum SDI in the lower Coastal Plain [36]. We established a cutoff limit of 50\% of maximum SDI to determine thinning ages-for slash pine whose SDI is 990 (metric units) [34].

With this approach, two thinning schedules were timed for a TPDs between 1000 and 1500 trees $\cdot h^{-1}$ _e.g., TPD $=1500$ trees $\cdot$ ha $^{-1}$, thinning at ages 13 and 17 years (Table 2 ). This approach also allowed for an extra thinning to be included in order to increase water yield with TPDs greater than 1500 trees $\cdot \mathrm{ha}^{-1}$. This methodology also indicated that, as TPDS increases, the thinning regimes ought to be scheduled earlier since the competition for resources also start earlier (Table 2). Our chosen thinning schedules and intensities are in sync with ranges reported for slash pine in the southeastern U.S. [37]. Furthermore, for our simulation, we assumed a maximum thinning intensity rate of $33 \%$. This can be considered a conservative estimate since thinnings up to $50 \%$ of tree removal can substantially increase water yield [15]. However, heavily thinned forests may yield lower economic profits due to low timber quality.

\subsection{Economic Paramaters}

The following average Florida stumpage prices, between 2010 and 2015, for sawtimber, chip-and-saw, and pulpwood were used in our analysis, respectively: $\$ 32.8 \mathrm{Mg}^{-1}, \$ 22.1 \mathrm{Mg}^{-1}$, and $\$ 14.7 \mathrm{Mg}^{-1}$ [38-43]. All nominal prices were deflated (base year 2015) using the producer price index logging industry [44]. Regeneration costs were based on Barlow and Levendis [45]. Costs of $\$ 237 \mathrm{ha}^{-1}$ and $\$ 109 \mathrm{ha}^{-1}$ were assumed, respectively, for site preparation and chemical herbaceous weed control at the moment of establishment. Planting and seedling costs were also assumed to be $\$ 91 \mathrm{ha}^{-1}$ and $\$ 0.05$ seedling $^{-1}$, respectively. Total regeneration costs were dependent on initial tree planting density, which varied between $\$ 487 \mathrm{ha}^{-1}$ and $\$ 562 \mathrm{ha}^{-1}$ for TPDS $=1000$ trees $\cdot \mathrm{ha}^{-1}$ and 
2500 trees $\cdot \mathrm{ha}^{-1}$, respectively. The real discount rate was assumed to be 0.04 , reflecting the $3 \%-5 \%$ range of values commonly used to assess forest investments in the southern US (e.g., [30,46-48]).

In Florida, costs of water systems vary depending on supply sources: for example, the cost for traditional water supply sources, such as pumping groundwater from the upper Floridian aquifer, is around $\$ 0.07 \mathrm{~kL}^{-1}$, while the costs for desalination of coastal seawater range from $\$ 1.9$ and $\$ 2.2 \mathrm{~kL}^{-1}$ (original values in this study are in kilo-gallons) [49]. Since our study is meant to assess feasibility of using forests for water yield, we assumed the conservative cost estimate of groundwater pumped from the Floridian aquifer, $\$ 0.07 \mathrm{~kL}^{-1}$, to serve as benchmark, given that it reflects the more realistic water supply source that can be affected by changes in forest management. We also considered two additional prices for water, $\$ 0.03$ and $\$ 0.30 \mathrm{~kL}^{-1}$, to assess the economic implications of price variability on the management of slash pine forests in Florida.

\subsection{Model Application to Slash Pine Forests}

To ascertain the impacts of water payments on the profitability and optimal forest management of slash pine, we proceeded as follows. First, we employed the growth and yield model, and economic parameters for slash pine, to determine the timber economic benefits for the baseline scenarios using Equation (2). Second, we calculated the water yield parameter, $W$, for the each baseline scenario, with its respective thinning regime (Equations (4) and (5)), to determine the difference in water yield, $\Delta W$, and the water yield monetary benefits, $A(s)$ (Equation (6)). Finally, we determined the LEV for all thinning scenarios and for both tree-planting densities.

The rationale for comparing each intensive thinning scenario with its respective baseline is due to the concept of additionality: only compensating landowners for changes in water yield that would not have happened without the incentive. Thinnings are a common practice for southern pines to obtain larger forest products (sawtimber), and a side consequence is an increase in water yield following the thinnings. From a policy making perspective, the implementation of incentive programs must have a clear baseline otherwise non-additional water saving can undermine the program's economic effectiveness. Therefore, the economic incentive (payments for water yield) is paid for forest landowners is to conduct extra thinnings considering that total production of timber will decrease and the optimal harvest age will be extended. Thus, the increased water yield is the difference (delta) between the intensive thinning scenario and current forest management (extensive thinning scenario or baseline scenario). We take this approach since pricing the total water yield for any scenario without comparing to a baseline will overestimate the real impacts of forest management practices on water yield. Likewise, comparing water yields between baselines would not capture the efforts from landowners to increase water yield in forest systems, and the initial age of thinnings for each of the baseline scenarios are different given the upper growing stock level for each tree planting density, making the comparison between baselines problematic.

Our analysis also defined two other indices of economic efficiency in terms of monetary benefits and improvements in water yield: (i) EE- $\Delta \mathrm{W}$, which is the ratio of economic rents $\left(L E V, \$ \cdot \mathrm{ha}^{-1}\right)$ to increased water yield $(\Delta W, \mathrm{~kL})$ index that reflects total gains in economic rents (wood and water benefits) per unit of increased water yield for a particular slash pine thinning management regime; and (ii) its marginal analog, $\Delta \mathrm{EE}-\Delta \mathrm{W}$, which represents the ratio between the difference in economic rents of an intensive thinning scenario (wood and water benefits) versus the baseline scenario (wood benefits) $\left(\triangle L E V, \$ \cdot \mathrm{ha}^{-1}\right)$ and an increase in water yield $(\Delta W, \mathrm{~kL})$, and suggests whether managing slash pine forests for wood and water production is a better economic option when compared to managing slash pine for wood production only. 


\section{Results}

\subsection{Land Expectation Values and Optimal Forest Management}

Figure 1 presents the results for the land expectation values, and economic benefits from water yield production for each intensive thinning regime. This figure indicates that, for TPDs $=1000$ trees $\cdot \mathrm{ha}^{-1}$ and 1100 trees $\cdot \mathrm{ha}^{-1}$, the inclusion of intensive thinnings had no impact on the variation of the water yield with respect to their baselines ( $G=0$ for both TPDs). The differences in $L E V \mathrm{~s}$ with respect to their baselines for these levels of TPD were given by the extra economic benefits due to multiple thinnings. For TPDs greater than 1100 trees $\cdot$ ha $^{-1}$, managing slash pine for increased water yield realized greater economic revenues, as compared to managing the stand for the sole purpose of timber production (baseline). On average, compared to the baseline scenario, $L E V \mathrm{~s}$ were $12 \%$ greater in all intensive thinning scenarios. On relative terms, the difference in $L E V$ s between each thinning scenario and its baseline was reduced as the TPDs increased. At higher levels of TPDS (greater than $\$ 2200 \mathrm{ha}^{-1}$ ), the difference between economic rents were less than $2 \%$. Planting more slash pine trees with intensive thinnings resulted in higher economic rents when compared with lower planting densities and extensive thinnings (baseline). On average, this approach increased profits by $11 \%$ (\$192 $\mathrm{ha}^{-1}$ ) for each additional 100 trees $\cdot \mathrm{ha}^{-1}$ planted for the range of feasible planting densities that we considered.

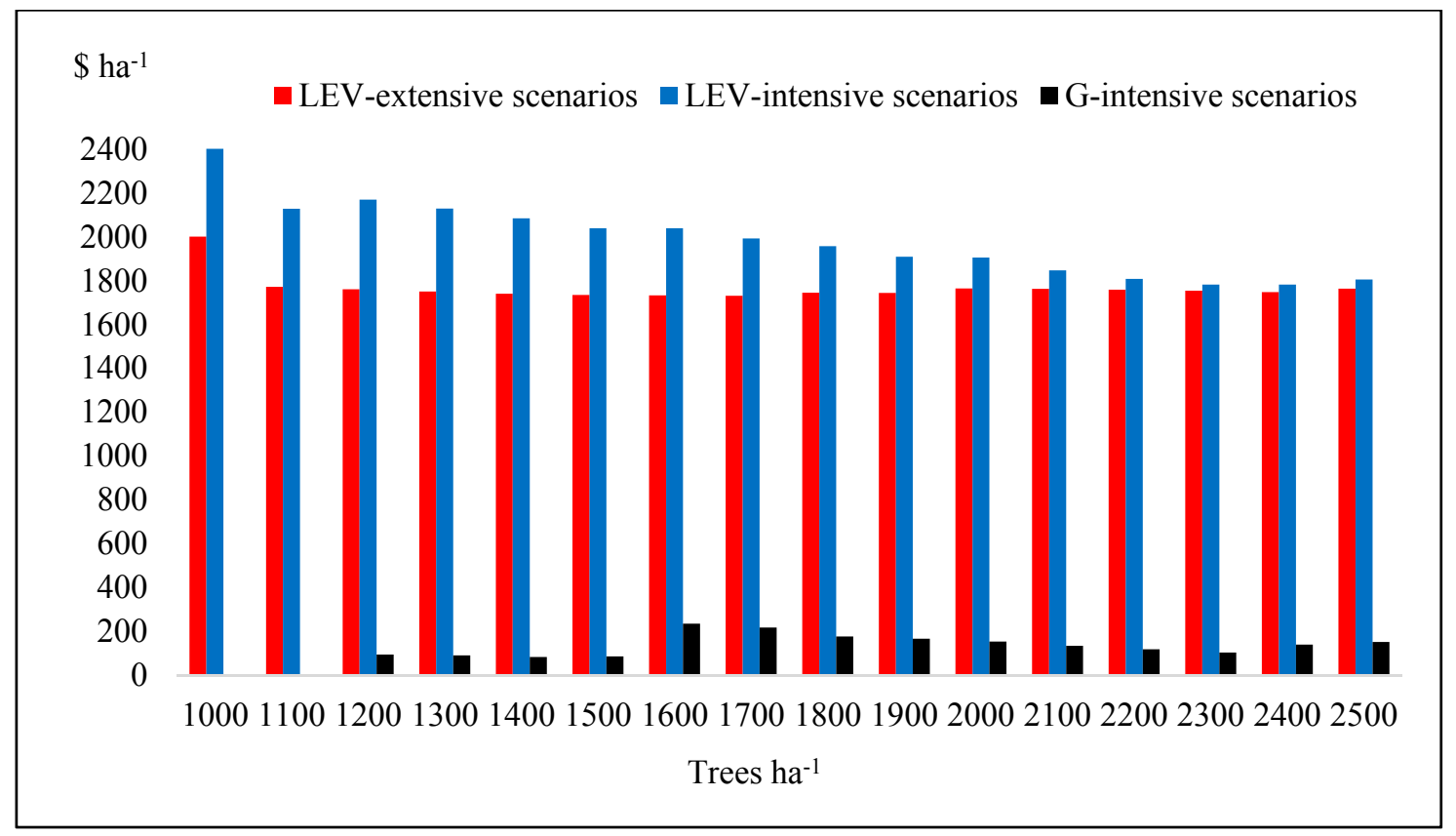

Figure 1. Land expectation value $(L E V)$ and water yield benefits $(G)$ for different slash pine planting densities and $P_{w}=\$ 0.07 \mathrm{~kL}^{-1}$.

When variations for water of yield were considered $(\Delta W)$, the best economic strategy was to intensively thin slash pine at ages 15 and 19 years $\left(\mathrm{TPD}=1200\right.$ trees $^{\circ} \mathrm{ha}^{-1}, L E V=\$ 2170 \mathrm{ha}^{-1}$ ) (Figure 1). The reduction of the basal area of slash pine through high thinning intensities with respect to the baseline also increased the $L A I$ of slash pine-reducing the difference between rainfall and watershed drainage [14], increasing water yield. The variations in water yield increased at the moment of thinnings. Between thinnings, the variations in water yield tended to decrease (Figure 2). 


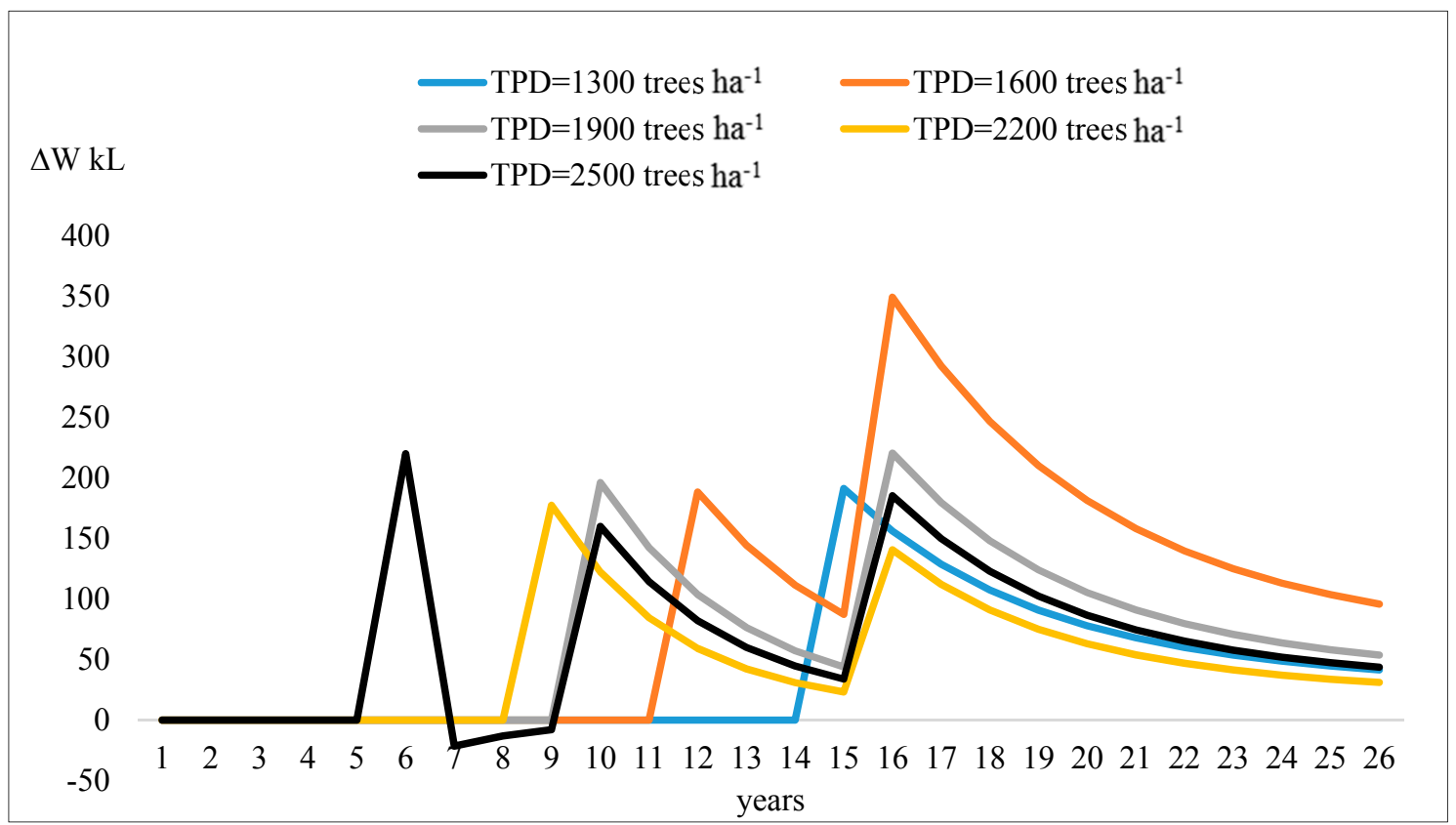

Figure 2. Variation of water yield $(\Delta W)$ for different tree planting densities (TPD).

As expected, intensive thinnings also extended the optimal harvest age for TPDs greater than 1500 trees $\cdot \mathrm{ha}^{-1}$, given that forest stands take a longer time to reach economic maturity (Table S1). The $L E V$ also increased with higher intensities of thinnings, due to perpetual payments for water yield $(G)$. The share of $G$ to the $L E V$ increased from $4.3 \%\left(G=\$ 93.7 \mathrm{ha}^{-1}, \mathrm{TPD}=1200\right.$ trees $\left.^{\circ} \mathrm{ha}^{-1}\right)$ to $11.3 \%$ $\left(G=\$ 235 \mathrm{ha}^{-1}, \mathrm{TPD}=1600\right.$ trees$\cdot \mathrm{ha}^{-1}$ ) (Figure 1). Although the share of $G$ to the $L E V$ decreased with TPDs greater than 1600 trees.ha $^{-1}$, they were greater than those with less number of thinnings (TPDS $=1200$ to 1500 trees $\cdot$ ha $^{-1}$ ).

As expected, the profitability of slash pine forests decreased (increased) with lower (greater) payments for water yield (Figure 3). On average, for a $P_{w}=\$ 0.03$ and $\$ 0.30 \mathrm{~kL}^{-1}$ $\left(\mathrm{TPD}=1500\right.$ trees $\left.\cdot \mathrm{ha}^{-1}\right)$, the $L E V$ decreased and increased, respectively, by $4 \%$ and $20 \%$, for all scenarios, compared to those for a $P_{w}=\$ 0.07 \mathrm{~kL}^{-1}$. Furthermore, the proportion of $G$ to the $L E V$ decreased and increased, respectively, to $3 \%$ and $23 \%$ (Table S2). The best economic scenario for an increased price for water yield was to thin at ages 12,16 , and 22 years (TPD $=1600$ trees $^{-h^{-1}}{ }^{-1}$ ) (Figure 3), $G=\$ 940 \mathrm{ha}^{-1}$, around $34 \%$ of total economic rents (Table S2). Compared to the baseline scenarios, on average, managing slash pine for timber and water production yielded $8 \%$ and $33 \%$ greater LEVs for $P_{w}=\$ 0.03 \mathrm{~kL}^{-1}$ and $\$ 0.30 \mathrm{~kL}^{-1}$, respectively, than those obtained when slash pine was managed only for timber production. Furthermore, with high prices of water, planting an extra 100 trees.ha ${ }^{-1}$ improved the economic rents by $\$ 585 \mathrm{ha}^{-1}$ (33\%) compared to the baseline with lower planting densities. In the case of low payments for water yield $\left(P_{w}=\$ 0.03 \mathrm{~kL}^{-1}\right)$, landowners were better off managing slash pine for timber production for TPDs greater than 2200 trees.ha $^{-1}$ (Figures 1 and 3).

It is important to note that changes in payments for water yield did not have an impact on the optimal harvest age for scenarios with the same level of thinning-the variation in water yield $\Delta W$ remained the same compared to the original payments for water yield (Table S2). This was due to the perpetual marginal benefits of increased water yield, which did not have a significant variation given that the slash pine stand was already close to the economic optimal rotation. 


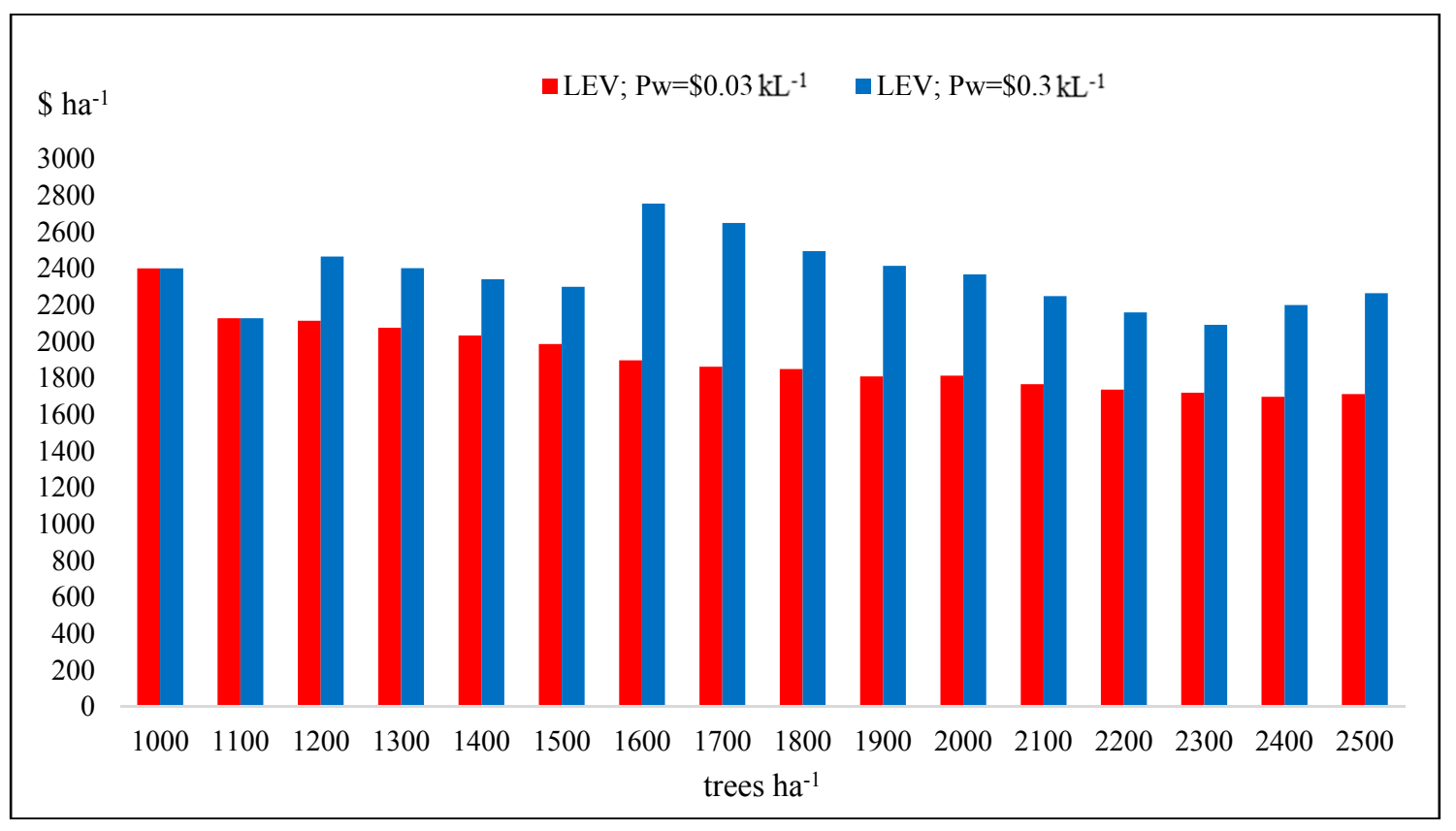

Figure 3. $L E V$ for different slash pine planting densities and prices of water.

\subsection{Economic Efficiency Analysis}

Managing slash pine with a less intensive silviculture treatment was more economically efficient in terms of increasing water yield. For example, on average, a $1 \mathrm{~kL}$ of increased water yield generated $\$ 39 \mathrm{ha}^{-1}$ for TPDs $=1200$ to 1500 trees $\cdot \mathrm{ha}^{-1}$, while for TPDs $=1600$ to 2500 trees $\cdot \mathrm{ha}^{-1}$ (for $P_{w}=0.07 \mathrm{~kL}^{-1}$ ) it generated $\$ 37 \mathrm{ha}^{-1}$, respectively (Table 3). The most economically efficient scenarios were those with early and intensive thinnings (TPDs $=2300-2400$ trees $^{-h^{-1}}{ }^{-1}$ ), which increased the economic rents by around $\$ 56 \mathrm{ha}^{-1}$ and $\$ 57 \mathrm{ha}^{-1}$ for $1 \mathrm{~kL}$ on increased water yield (Table 3). With higher prices of water, it was more economically efficient to heavily thin slash pine forest. On average, given $P_{w}=\$ 0.30 \mathrm{~kL}^{-1}$, a $1 \mathrm{~kL}$ of increased water yield generated $\$ 46 \mathrm{ha}^{-1}$ for TPDs $=1600$ to 2500 trees $\cdot \mathrm{ha}^{-1}$, while for TPDs $=1200$ to 1500 trees $\cdot \mathrm{ha}^{-1}$ it generated $\$ 44 \mathrm{ha}^{-1}$. As with a lower price for water, the most efficient economic scenarios were TPDs $=2300-2400$ trees $\cdot$ ha $^{-1}$ —around $\$ 66$ and $\$ 70 \mathrm{ha}^{-1}$ were generated when water yield was increased by $1 \mathrm{~kL}$ in slash pine forests, respectively.

At the margin, higher water prices also generated greater differences in economic rents between managing slash pine for timber/water production and managing slash pine only for timber production (Table 3). This finding was more robust for scenarios with fewer and lower intensity of thinnings. For example, for TPDs $=1200$ trees $\cdot \mathrm{ha}^{-1}$ to 1500 trees $\cdot \mathrm{ha}^{-1}\left(P_{w}=\$ 0.30 \mathrm{Kgal}^{-1}\right)$, given a $1 \mathrm{~kL}^{-1}$ increase in the water yield due to thinning regimes, the $L E V$ increased, on average, by $\$ 12 \mathrm{ha}^{-1}$, as compared to the $L E V$ based on sole timber production. For increased TPDS (Scenarios B6 to B15), this increase was $\$ 11 \mathrm{ha}^{-1}$ given a $1 \mathrm{~kL}^{-1}$ increase in the water yield. On average, the net benefits of managing slash pine for water and timber production, with $P_{w}=\$ 0.03$ and $\$ 0.07 \mathrm{~kL}^{-1}$, were $\$ 1.8$ and $\$ 3.3 \mathrm{ha}^{-1}$, as compared to the rents generated for managing the stand solely for timber production, for all scenarios. In the case of increased tree planting density, the marginal benefits of timber and water production were only positive for moderate and high water prices. For low water prices $\left(\$ 0.03 \mathrm{~kL}^{-1}\right)$, a $1 \mathrm{~kL}$ increase in the water yield led to average losses of $\$ 1 \mathrm{ha}^{-1}$ in land values and for TPDs greater than 2200 trees $\mathrm{ha}^{-1}$ (Table 3). 
Table 3. Economic efficiency of increased water yield (EE- $\Delta \mathrm{W}, \Delta \mathrm{EE}-\Delta \mathrm{W}$ ) for slash pine thinning scenarios.

\begin{tabular}{|c|c|c|c|c|c|c|}
\hline \multirow[b]{3}{*}{ TPD } & \multicolumn{6}{|c|}{ Water Price $\$ \cdot \mathbf{k L}^{-1}$} \\
\hline & \multicolumn{2}{|c|}{0.03} & \multicolumn{2}{|c|}{0.07} & \multicolumn{2}{|c|}{0.30} \\
\hline & EE- $\Delta \mathbf{W}$ & $\Delta \mathrm{EE}-\Delta \mathbf{W}$ & EE- $\Delta \mathbf{W}$ & $\Delta \mathrm{EE}-\Delta \mathbf{W}$ & EE- $\Delta \mathbf{W}$ & $\Delta \mathrm{EE}-\Delta \mathbf{W}$ \\
\hline Trees $\cdot h^{-1}$ & \multicolumn{6}{|c|}{$\$ \cdot h a^{-1} \cdot \mathrm{kL}^{-1}$} \\
\hline 1000 & n.a & n.a & n.a & n.a & n.a & n.a \\
\hline 1100 & n.a & n.a & n.a & n.a & n.a & n.a \\
\hline 1200 & 26.0 & 4.3 & 26.7 & 5.0 & 30.3 & 8.7 \\
\hline 1300 & 34.6 & 5.4 & 35.5 & 6.3 & 40.0 & 10.9 \\
\hline 1400 & 40.6 & 5.8 & 41.6 & 6.9 & 46.7 & 12.0 \\
\hline 1500 & 51.1 & 6.5 & 52.4 & 7.8 & 59.1 & 14.5 \\
\hline 1600 & 18.3 & 1.6 & 19.7 & 2.9 & 26.6 & 9.9 \\
\hline 1700 & 21.7 & 1.5 & 23.2 & 3.1 & 30.8 & 10.7 \\
\hline 1800 & 24.1 & 1.4 & 25.5 & 2.8 & 32.6 & 9.8 \\
\hline 1900 & 28.4 & 1.0 & 29.9 & 2.6 & 37.9 & 10.5 \\
\hline 2000 & 34.8 & 0.9 & 36.6 & 2.7 & 45.5 & 11.6 \\
\hline 2100 & 40.6 & 0.1 & 42.5 & 1.9 & 51.7 & 11.2 \\
\hline 2200 & 46.7 & -0.6 & 48.6 & 1.3 & 58.1 & 10.8 \\
\hline 2300 & 54.1 & -1.1 & 56.0 & 0.9 & 65.7 & 10.6 \\
\hline 2400 & 54.3 & -1.6 & 56.9 & 1.1 & 70.3 & 14.4 \\
\hline 2500 & 29.6 & -0.9 & 31.2 & 0.7 & 39.0 & 8.7 \\
\hline
\end{tabular}

\section{Discussion}

In this study, we considered payments to nonindustrial private forest landowners for increasing water yield through thinnings in slash pine forests. Our findings are consistent with related studies showing that thinnings are an efficient silvicultural tool for improving the sustainability of slash pine forests (e.g., [13,50]). Harnessing planted pine forests for water protection, through payment schemes, may become a vital strategy to protect water resources and maintain freshwater ecosystems [9]. Our results suggest that this approach may be both economically effective and beneficial to forest landowners in a slash pine context.

We also used a cost-based method estimate as a proxy to represent the benefits of water yield in forests. Our results indicated that, depending on the tree planting density and timing and intensity of thinning, economic benefits of managing slash pine for water production $(G)$ ranged from $\$ 34.1 \mathrm{ha}^{-1}$ $\left(1.4 \mathrm{ha}^{-1} \cdot\right.$ year $\left.^{-1}\right)$ to $\$ 940 \mathrm{ha}^{-1}\left(37.6 \mathrm{ha}^{-1} \cdot\right.$ year $^{-1}$ ) (Perpetual annual payments are obtained by multiplying the interest rate by the perpetual net benefits of water production $\mathrm{G}$ ). Our upper boundary estimate was within the range of values of related studies such as Costanza et al. [19] (66 ha $\left.{ }^{-1} \cdot \mathrm{year}^{-1}\right)$, Nunez et al. [24] (\$162 ha ${ }^{-1} \cdot$ year $\left.^{-1}\right)$ and Turner et al. [51] (\$245 ha ${ }^{-1} \cdot$ year $\left.^{-1}\right)$; however, our lower boundary estimate was lower than the estimates provided by said studies.

Our results indicated that forest landowners would be economically compensated for increasing water yield through thinnings if they planted more than 1100 trees $\mathrm{ha}^{-1}$. However, for heavily planted slash pine forests (2200 trees.ha ${ }^{-1}$ and more), and a moderate payment for water yield $\left(\$ 0.07 \mathrm{~kL}^{-1}\right)$, forest landowner may be indifferent between managing their forests for water production and timber production only. Planting more slash pine trees with intensive thinnings would improve the economic rents for landowners by $11 \%$ on average with respect to the baseline with lower tree planting density -an extra $\$ 192 \mathrm{ha}^{-1}$ per extra 100 slash pine trees planted. With low payments for water yield $\left(\$ 0.03 \mathrm{~kL}^{-1}\right)$, and heavily planted forests (greater than 2200 trees $\cdot \mathrm{ha}^{-1}$ ), forest landowners would be economically worse off managing slash pine for water production than managing their forests for timber production only, averaging economic losses of $\$ 39 \mathrm{ha}^{-1}$. However, for moderate prices of water yield, managing slightly more than 1 ha of slash pine with intensive thinning regimes and high tree planting density $\left(\mathrm{TPDs}=2200-2500\right.$ trees $\cdot \mathrm{ha}^{-1}$ ) is preferred to the economic losses of managing slash 
pine with low prices of water. On average for all TPDS, the economic gains with moderate prices of water exceeded the economic rents for managing the stand solely for timber production by $\$ 3.3 \mathrm{ha}^{-1}$.

It is important to point out that slash pine forests can also provide other ecosystem services such as pine-straw production or carbon sequestration, and landowners might have different management objectives that are not consistent with income maximization. Our findings are bound to the assumptions depicted in our model and should be carefully interpreted as such. For example, for either low-to-moderate or high water prices, the use of thinnings would likely reduce the supply of pulpwood at the moment of the final harvest, which may cause upward pressure on the price of this forest product if enough landowners do the same. This could be another factor that may augment the sustainability of Florida's forests, namely, the positive effects on pine pulpwood prices as a result of forest water management practices may support the already strong trends of high stumpage prices for this forest output since 2010 - an existing trend that is due to increased production from the packing industry and reinforced by high stumpage prices for pine pulpwood since 2010 [43].

Our results indicated that, on average, for all tree planting densities and the entire range of harvest ages, one hectare of intensively thinned slash pine forest provides around $1 \%$ more water yield (approximately $4 \mathrm{~kL}$ more) than one ha of lightly thinned slash pine. This is important given the extent of slash pine in Florida-around 2.2 million ha in FL, or 33\% of the state's forestlands, are classified as longleaf-slash pine forest type [49]. Diversifying the financial basis for slash pine forests and increasing their economic resilience through payments for increased water yield is critical given ongoing human- and climate-related forest disturbance issues. For example, higher temperatures and increased conversion rates of forestland to other uses can decrease water supply available for human consumption [2]. This is particularly germane in Florida, where watersheds in private forests, which have a greater percentage of water available for consumption [2], are expected to experience significant increases in housing densities [9] and in-migration of irrigated row-crop agriculture from drought-stricken California. This can also have a significant impact on low-income households. Studies have shown that reductions in forestlands would increase water treatment costs, which lead to higher water prices for end users [52].

A critical assumption of our analysis is that forest landowners are economically compensated to increase water yield through thinnings. There are some forest conservation programs such as the Florida Forever Program, which acquires lands to protect Florida's surface and groundwater quality, and conserve other ecosystem services; and the Florida Forest Stewardship Program, an education program that assists non-industrial private landowners in managing their lands for long-term environmental, and economic benefits. However, these programs do not provide direct economic incentives to landowners to manage their forest for water production. A notable exception is the Conservation Reserve Program administered by the USDA, through which the federal government provides rental payments and cost share assistance for forest landowners to manage their lands for water conservation. We strongly believe that this type of economic analysis will help policy makers to strengthen existing and amply different incentive programs for forest based water conservation programs.

The implications of managing slash pine forests for water yield are apparent when considering the water use requirements of large metropolitan areas in Florida. At the state-wide level, the total amount of water withdrawals for public consumption was around 3,169,295 million liters per year in 2012 [53]. If all of Florida's slash pine forests were managed for water production, the difference in water yield between thinned and unthinned slash pine forests-approximately 125,400 million liters-would contribute roughly $4 \%$ of the total withdrawal of water for public use (Please note that these aggregated estimates of forest water yield production need to be understood within the context of: (1) all Florida slash pine hectares following the same forest management treatments from Table 2; and (2) all Florida slash pine hectares having the same optimal harvest ages found in Tables S1 and S2). This would be a significant increase in water available for consumptive water use (e.g., to support water-constrained cities) and for environmental flows. These estimates can also be used to help gauge 
sustainability in the context of population and forest cover in the state. Given the state's current population and annual water use, on a per-capita basis it would take 2.93 ha of slash pine managed for water yield to provide adequate water based on current consumption patterns. Using this number as a guide, the state's slash pine forests, if managed for water yield, would provide additional water nearly equal to water use by the people of the state's most populous city-Jacksonville (with over 820,000 residents).

An important limitation to our modeling approach is the exclusion of understory control during mid-rotation. We note that weed control might be needed as suggested by McLaughlin et al. [14], Jokela et al. [54] and Nettles [55]. In these papers, the authors analyzed existing southern pines stands and quantified the effect of understory vegetation on the evapotranspiration and forest productivity. However, our growth and yield model for slash pine used in our analysis is calibrated only for weed control at the moment of establishment. Thus, in our model, adding mid-rotation herbaceous weed control would only have an economic impact (as a cost) but it would not be reflected in changes in the biological parameters of the forest stand. We also recognize that our analysis is a simplification of the reality: changes in water yield may not necessarily imply that water savings will be delivered to the downstream unless changes in forest management are carried out at the landscape level. As suggested by Nettles [55], if the forest landscape is treated similarly for water production over a long term, it will be likely to obtain a permanent source of downstream water. This is a focus of future research.

As water production becomes a policy priority, private forest landowners may benefit from the development of stronger markets for forest-based water production. More sources for water provision and investment in cost efficient technologies would also improve the sustainability of water production, while reducing water costs for the end users [49]. However, the development of this new market on the producer side may be slow. Furthermore, as demand pressures are expected to increase both water prices and freshwater withdrawals in Florida, these factors could incentivize the development of more efficient technologies, which could mitigate the demand effects [56].

It is imperative that we develop adequate water valuation models that inform policy decisions, and include both demand- and supply-side values. To date, much of the valuation work related to water and ecosystems has relied on stated preferences approaches (e.g., asking consumers what they would be willing to pay) [21]. The use of production functions (benefit transfer methods) and hedonic prices, combined with biophysical measurements, are also suitable techniques to estimate the monetary value of forest based water production [23,24]. Given the extent of privately-owned forests in the Southeastern U.S., it is necessary to consider not just the benefits of managing forests for ecosystem service benefits to society, but also costs to the forest landowner of providing these services, and the role of policies and programs to provide adequate incentives and help mitigate these costs to ensure the provision of these services.

\section{Conclusions}

Our study assessed the economic implications of managing slash pine forests in Florida for increased water yield. We simulated changes in water yield for tree planting densities varying from 1000 to 2500 trees ha $^{-1}$ through multiple thinning regimes. With initials tree planting density greater than 1200 trees.ha ${ }^{-1}$, our findings indicate that managing slash pine forests for timber production and increased water yield was economically preferred to the sole production of timber at moderate and high water price levels. However, with higher levels of initial tree planting density (greater than 2200 trees $\cdot \mathrm{ha}^{-1}$ ) and low to moderate water prices, managing slash pine for timber production was more profitable than managing for the combined options of timber and water production.

Planting fewer slash pine trees (1600 tress $\cdot \mathrm{ha}^{-1}$ or less) was also more economically effective than planting scenarios with increased number of slash pine trees. This practice generated more revenues per unit of increased water yield, which was accentuated at higher water prices. Furthermore, from an economic efficiency perspective, planting fewer slash pine trees per hectare generated more revenues than scenarios with only timber production per unit of increased water yield-given all water prices 
that we considered. In the case of increased tree planting density, water and timber production was also the more efficient option, as compared to sole production of timber, with high prices of water. We expect that our findings bring more awareness of the vital importance of water production as a forest based ecosystem service, along with a heightened awareness of the contribution of forest based water production towards improving the sustainability of southern pines in the state of Florida.

Supplementary Materials: The following are available online at www.mdpi.com/2073-4441/8/9/382/s1, Table S1: Variations in water yield $(\Delta W)$ at the optimal harvest age $\left(T^{*}\right)$ for different slash pine planting densities and $P_{w}=\$ 0.07 \mathrm{~kL}^{-1}$, Table S2: Water yield benefits $(\mathrm{G})$, and variations in water yield $(\Delta W)$ at the optimal harvest age $\left(T^{*}\right)$ for different slash pine planting densities and $P_{w}=\$ 0.03$, and $0.3 \mathrm{~kL}^{-1}$.

Acknowledgments: This work is supported by The Pine Integrated Network: Education, Mitigation, and Adaptation project (PINEMAP); a Coordinated Agricultural Project funded by the USDA National Institute of Food and Agriculture, Award \#2011-68002-30185. The authors would like to thank Matt Cohen, Carlos Gonzalez-Benecke and Eric Jokela for their valuable comments in the preparation of the manuscript.

Author Contributions: The paper was written by Andres Susaeta with significant contribution by José R. Soto and Damian C. Adams. Andres Susaeta, José R. Soto, and Damian C. Adams identified the research questions and designed the study with contributions from Derek L. Allen. Andres Susaeta performed the economic analyses with guidance from co-authors.

Conflicts of Interest: The authors declare no conflict of interest.

\section{Abbreviations}

The following abbreviations are used in this manuscript:

LEV

TPD

$L A I$

land expectation value

tree planting density

leaf area index

\section{References}

1. Oswalt, S.N.; Smith, W.B.; Miles, P.D.; Pugh, S.A. Forest Resources of the United States, 2012: A Technical Document Supporting the Forest Service 2015 Update of the RPA Assessment; General Technical Report GTR-WO-91; U.S. Department of Agriculture Forest Service Washington Office: Washington, DC, USA, 2014.

2. Lockaby, G.; Nagy, C.; Vose, J.; Ford, C.; Sun, G.; Mcnulty, S.G.; Caldwell, P.V.; Cohen, E.; Moore Myers, J. Forests and water. In The Southern Forest Futures Project: Technical Report; Wear, D.N., Greis, J., Eds.; General Technical Report SRS-178; U.S. Department of Agriculture Forest Service Southern Research Station: Asheville, NC, USA, 2013; pp. 309-339.

3. De Groot, R.S.; Wilson, M.A.; Boumans, R.M.J. A typology for the classification, description and valuation of ecosystem functions, goods and services. Ecol. Econ. 2002, 41, 393-408. [CrossRef]

4. Caldwell, P.; Muldoon, C.; Miniat, C.F.; Cohen, E.; Krieger, S.; Sun, G.; Mcnulty, S.; Bolstad, P.V. Quantifying the Role of National Forest System Lands in Providing Surface Drinking Water Supply for the Southern United States; General Technical Report SRS-197; Department of Agriculture Forest Service Southern Research Station: Asheville, NC, USA, 2014.

5. Wertin, T.M.; McGuire, M.A.; Teskey, R.O. Effects of predicted future and current atmospheric temperature and $\left(\mathrm{CO}_{2}\right)$ and high and low soil moisture on gas exchange and growth of Pinus taeda seedlings at cool and warm sites in the species range. Tree Physiol. 2012, 32, 847-858. [CrossRef] [PubMed]

6. Peterson, D.L.; Wolken, J.M.; Hollingsworth, T.N.; Giardina, C.P.; Littell, J.S.; Joyce, L.A.; Swanston, C.W.; Handler, S.D.; Rustad, L.E.; Mcnulty, S.G. Regional highlights of climate change. In Climate Change and United States Forests; Peterson, D.L., Vose, J.M., Patel-Weynand, T., Eds.; Springer Science+Business Media: New York, NY, USA, 2014; p. 261.

7. Karl, T.R.; Melillo, J.M.; Peterson, T.C. Global Climate Change Impacts in the United States; Cambridge University Press: New York, NY, USA, 2009.

8. Martinuzzi, S.; Stewart, S.; Helmers, D.; Mockrin, M.; Hammer, R.; Radeloff, V. The 2010 Wildland-Urban Interface of the Conterminous United States; Research Map NRS-8; U.S. Department of Agriculture Forest Service Northern Research Station: Newton Square, PA, USA, 2010. 
9. Mockrin, M.H.; Lilja, R.L.; Weidner, E.; Stein, S.M.; Carr, M.A.; Service, F. Private Forests, Housing Growth, and America's Water Supply a Report from the Forests on the Edge and Forests to Faucets Projects; General Technical Report RMS-GTR-327; U.S. Department of Agriculture Forest Service Rocky Mountain Research Station: Fort Collins, CO, USA, 2014.

10. Glasser, S.; Gauthier-Warinner, J.; Gurrieri, J.; Keely, J.; Tucci, P.; Summers, P.; Wireman, M.; McCormack, K. Technical Guide to Managing Ground Water Resources; FS-881; U.S. Department of Agriculture Forest Service; U.S. Geological Survey; Bureau of Land Management; U.S. Environmental Protection Agency: Washington, DC, USA, 2007.

11. Duerr, D.; Mistretta, P. Invasive pests-insects and diseases. In The Southern Forest Futures Project: Technical Report; Wear, D., Greis, J., Eds.; General Technical Report SRS-178; U.S. Department of Agriculture Forest Service: Asheville, NC, USA, 2013; pp. 407-508.

12. Stanturf, J.A.; Goodrick, S.L. Fire. In The Southern Forest Futures Project: Technical Report; Wear, D., Greis, J., Eds.; General Technical Report SRS-178; U.S. Department of Agriculture Forest Service Southern Research Station: Asheville, NC, USA, 2013; p. 542.

13. Demers, C.; Andreu, M.; McGowan, B.; Long, A.; Nowak, J. Thinning Southern Pines-A Key to Greater Returns; SS FOR24; University of Florida School of Forest Resources and Conservation: Gainesville, FL, USA, 2005.

14. McLaughlin, D.L.; Kaplan, D.A.; Cohen, M.J. Managing forests for increased regional water yield in the southeastern U.S. Coastal Plain. JAWRA J. Am. Water Resour. Assoc. 2013, 49, 953-965. [CrossRef]

15. Sun, G.; Caldwell, P.V.; Mcnulty, S.G. Modelling the potential role of forest thinning in maintaining water supplies under a changing climate across the conterminous United States. Hydrol. Process. 2015, 29, 5016-5030. [CrossRef]

16. McCarthy, E.J.; Skaggs, R.W. Simulation and evaluation of water management systmes for a pine plantation watershed. South. J. Appl. For. 1992, 16, 44-52.

17. Grace, J.M.; Skaggs, R.W.; Chescheir, G.M. Hidrologic and water quality effects of thinning loblolly pine. Trans. Agric. Biol. Eng. 2006, 49, 645-654.

18. Edwards, P.J.; Troendle, C.A. Water yield and hidrology. In Cumulative Watershed Effects of Fule Management in the Eastern United States; General Technical Report SRS-161; Lafayette, R., Brooks, M., Potyond, J., Audin, L., Krieger, S., Trettin, C., Eds.; U.S. Department of Agriculture Forest Service Southern Research Station: Asheville, NC, USA, 2012; pp. 229-281.

19. Costanza, R.; de Groot, R.; Sutton, P.; van der Ploeg, S.; Anderson, S.J.; Kubiszewski, I.; Farber, S.; Turner, R.K. Changes in the global value of ecosystem services. Glob. Environ. Chang. 2014, 26, 152-158. [CrossRef]

20. Kreye, M.; Adams, D.; Escobedo, F. The value of forest conservation for water quality protection. Forests 2014, 5, 862-884. [CrossRef]

21. Elias, E.; Laband, D.; Dougherty, M.; Lockaby, G.; Srivastava, P.; Rodriguez, H. The public water supply protection value of forests: A watershed-scale ecosystem services analysis based upon total organic carbon. Open J. Ecol. 2014, 4, 517-531. [CrossRef]

22. Wilson, M.A.; Carpenter, C.R. Economic valuation of freshwater ecosystem services in the US: 1971-1997. Ecol. Appl. 1999, 9, 772-782.

23. Costanza, R.; Wilson, M.; Troy, A.; Voinov, A.; Liu, A.; D'Agostina, J. The Value of New Jersey's Ecosystem Services and Natural Capital; Gund Institute for Ecological Economics Robinson; School of Environment and Natural Resources University of Vertmont: Burlington, VT, USA, 2006.

24. Nunez, D.; Nahuelhual, L.; Oyarzun, C. Forests and water: The value of native temperate forests in supplying water for human consumption. Ecol. Econ. 2006, 58, 606-616. [CrossRef]

25. Boyer, T.; Polasky, S. Valuing urban wetlands: A review of non-market valuation studies. Wetlands 2004, 24, 744-755. [CrossRef]

26. Barnett, J.; Sheffield, R. Slash pine: Characteristics, history, status, and trends. In Slash Pine: Still Growing and Growing!; General Technical Report GTR SRS-76; Dickens, E.D., Barnet, J.P., Hubbard, W.G., Jokela, E.L., Eds.; U.S. Department of Agriculture Forest Service: Asheville, NC, USA, 2004; pp. 1-6.

27. Florida Department of Agriculture and Consumer Services. 2013 Florida Forestry Economic Highlights. Available online: http:/ /floridaforest.org/wp-content/uploads/Media_Files_Florida-Forest-Service-Files_ 2013EconomicHighlights.pdf (accessed on 10 February 2016).

28. Hartman, R. The harvesting decision when a standing forest has value. Econ. Inq. 1976, 14, 52-58. [CrossRef]

29. Samuelson, P. Economics of forestry in a evolving society. Econ. Inq. 1976, 14, 466-492. [CrossRef] 
30. Stainback, G.A.; Alavalapati, J.R.R. Economic analysis of slash pine forest carbon sequestration in the southern US. J. For. Econ. 2002, 117, 105-117.

31. Pienaar, L.V.; Shiver, B.D.; Rheney, J.W. Yield Prediction for Mechanically Site_Prepared Slash Pine Plantations in the Southeastern Coastal Plain; PMRC Technical Report 1996-3A; University of Georgia: Athens, GA, USA, 1996.

32. Yin, R.; Pienaar, L.V.; Arrow, M.E. The productivity and profitability of fiber farming. J. For. 1998, 96, 13-18.

33. Pienaar, L.V. Results and Analysis of a Slash Pine Spacing and Thinning Study in the Southeastern Coastal Plain; Technical Report 1995-3; University of Georgia: Athens, GA, USA, 1995.

34. Reineke, L.H. Perfecting a stand-density index for even-aged forests. J. Agric. Res. 1933, 46, 627-638.

35. Gonzalez-Benecke, C.A.; Jokela, E.J.; Martin, T.A. Modeling the effects of stand development, site quality, and silviculture on leaf area index, litterfall, and forest floor accumulations in loblolly and slash pine plantations. For. Sci. 2012, 58, 457-471. [CrossRef]

36. Dean, T.J.; Jokela, E.J. A density-management diagram for slash pine plantations in the lower Coastal Plain. South. J. Appl. For. 1992, 16, 179-185.

37. Gonzalez-Benecke, C.A.; Martin, T.A.; Cropper, W.P.; Bracho, R. Forest management effects on in situ and ex situ slash pine forest carbon balance. For. Ecol. Manag. 2010, 260, 795-805. [CrossRef]

38. Timber Mart-South. U.S. South Annual Review: 2010 Timber Prices \& Markets; Timber-Mart South: Athens, GA, USA, 2011.

39. Timber Mart-South. U.S. South Annual Review: 2011 Timber Prices \& Markets; Timber-Mart South: Athens, GA, USA, 2012.

40. Timber Mart-South. U.S. South Annual Review: 2012 Timber Prices \& Markets; Timber-Mart South: Athens, GA, USA, 2013.

41. Timber Mart-South. U.S. South Annual Review: 2013 Timber Prices \& Markets; Timber-Mart South: Athens, GA, USA, 2014.

42. Timber Mart-South. U.S. South Annual Review: 2014 Timber Prices \& Markets; Timber-Mart South: Athens, GA, USA, 2015.

43. Timber Mart-South. U.S. South Annual Review: 2015 Timber Prices \& Markets; Timber-Mart South: Athens, GA, USA, 2016.

44. United States Department of Labor Bureau of Labor Statistics. Databases, Tables and Calculators by Subject. Available online: http:/ / www.bls.gov/data / (accessed on 20 March 2016).

45. Barlow, R.; Levendis, W. 2014 Cost and cost trends for forestry practices in the South. For. Landowner 2015, September, 23-31.

46. Amacher, G.S.; Malik, A.S.; Haight, R.G. Forest landowner decisions and the value of information under fire risk. Can. J. For. Res. 2005, 35, 2603-2615. [CrossRef]

47. Susaeta, A.; Carter, D.R.; Adams, D.C. Sustainability of forest management under changing climatic conditions in the southern United States: Adaptation strategies, economic rents and carbon sequestration. J. Environ. Manag. 2014, 139, 80-87. [CrossRef] [PubMed]

48. Dwivedi, P.; Alavalapati, J.R.R.; Susaeta, A.; Stainback, A. Impact of carbon value on the profitability of slash pine plantations in the southern United States: An integrated life cycle and Faustmann analysis. Can. J. For. Res. 2009, 39, 990-1000. [CrossRef]

49. Florida Department of Environmental Protection. Report on Expansion of Beneficial Use of Reclaimed Water, Stormwater and Excess Surface Water; Senate Bill 536; Florida Department of Environmental Protection Office of Water Policy: Tallahassee, FL, USA, 2015.

50. Gonzalez-Benecke, C.A.; Susaeta, A.; Martin, T.A.; Jokela, E.J.; Carter, D.R. Balancing revenue and nutrient removals in Pinus elliotti Engelm. Stands managed for pinestraw and wood production. For. Sci. 2014, 60, $43-56$.

51. Turner, M.G.; Odum, E.P.; Costanza, R.; Springer, T.M. Market and non-market value of the Georgia landscape. Environ. Manag. 1998, 12, 209-217. [CrossRef]

52. Postel, S.; Thompson, B.H. Watershed protection: Capturing the benefits of nature's water supply services. Nat. Resour. Forum 2005, 29, 98-108. [CrossRef]

53. Marella, R.L. Water Withdrawals in Florida, 2012; Open-File Report 2015-1156; U.S. Geological Survey: Orlando, FL, USA, 2015. 
54. Jokela, E.J.; Martin, T.A.; Vogel, J.G. Twenty-five years of intensive forest management with southern Pines: Important lessons learned. J. For. 2010, 10, 338-347.

55. Nettles, J. Water management and productivity in planted forests. In Evolving Water Resources Systems: Understanding, Predicting and Managing Water-Society Interactions, Proceedings of the ICWRS2014, Bologna, Italy, 4-6 June 2014; IAHS Publication: Wallingford, Oxfordshire, UK, 2014; pp. 82-87.

56. Asci, S.; Borisova, T.; Dukes, M. Price- and Non-Price Water Demand Management Strategies for Water. In Proceedings of the Southern Agricultural Economics Association's 2015 Annual Meeting, Atlanta, GA, USA, 31 January-3 February 2015.

(C) 2016 by the authors; licensee MDPI, Basel, Switzerland. This article is an open access article distributed under the terms and conditions of the Creative Commons Attribution (CC-BY) license (http://creativecommons.org/licenses/by/4.0/). 